\title{
Variações sobre Vênus: \\ Botticelli, Ticiano e os tratados \\ sobre o amor
}

Tânia Kury Carvalho'

DOI 10.20396/eha.vil4.3468

Esta comunicação é dedicada ao estudo das variações na figuração da Vênus, conforme representadas: por Sandro Botticelli, no Nascimento de Vênus (Figura.1); por Giorgione da Castelfranco, na Vênus Adormecida (Figura.2); e por Ticiano, na Vênus de Urbino (Figura.3).

Investiga em que medida as definições e descrições da beleza presentes no Comentário sobre o Banquete, de Marsilio Ficino; nos Assolanos, de Pietro Bembo; e no Livro do Cortesão, de Baldassare Castiglione, que compartilham a definição de "amor como um desejo de beleza" e definem esta beleza com variações entre um conceito puramente metafísico - de uma beleza inteligível que visa à ascese espiritual - e uma concepção cada vez mais material - que rejeita a finalidade transcendente e assume uma beleza puramente física - podem estar representadas nas pinturas.

Neste estudo, foram isolados os conceitos artísticos ou as características físicas relacionadas às definições de beleza presentes nos textos, contrapondo-as às análises tradicionais das pinturas para, em seguida, comentar seu uso nas imagens. Foram consideradas as relações: entre as definições presentes no Comentário de Ficino, e a figuração da Vênus no Nascimento de Vênus, de Botticelli; entre as presentes nos Assolanos, de Bembo, e a figuração da Vênus Adormecida, de Ciorgione; e entre os conceitos e descrições de Bembo e Castiglione (matizadas por ideias de Agostino Nifo e Pietro Aretino) e a Vênus de Urbino, de Ticiano.

o Comentário sobre o Banquete foi o ponto de partida para a pesquisa. Ao definir a "beleza superior" por conceitos artísticos, Ficino terminou por, indiretamente, estabelecer "critérios" para sua representação. Este reconhecimento da beleza em dois níveis (terreno e divino), os quais poderiam conduzir a dois ou mais tipos de amor, estimulou o interesse sobre as sensações e intuições envolvidas no processo de cognição da beleza, seja em níveis físicos, metafísicos ou psicológicos, e o tema da "hierarquia dos sentidos" - que estabelece quais sentidos estariam mais aptos para a apreensão de qual beleza, e para o desencadeamento de qual amor - ocupou cada vez mais espaço

1 Mestranda em História da Arte - Universidade Federal de São Paulo - UNIFESP. 
[Figura 1] BOTTICELLI, Sandro. $O$ Nascimento de Vênus. c.

1485.

Têmpera sobre tela. 172.5 $\times 278.5 \mathrm{~cm}$. Galeria dos Ofícios - Florença

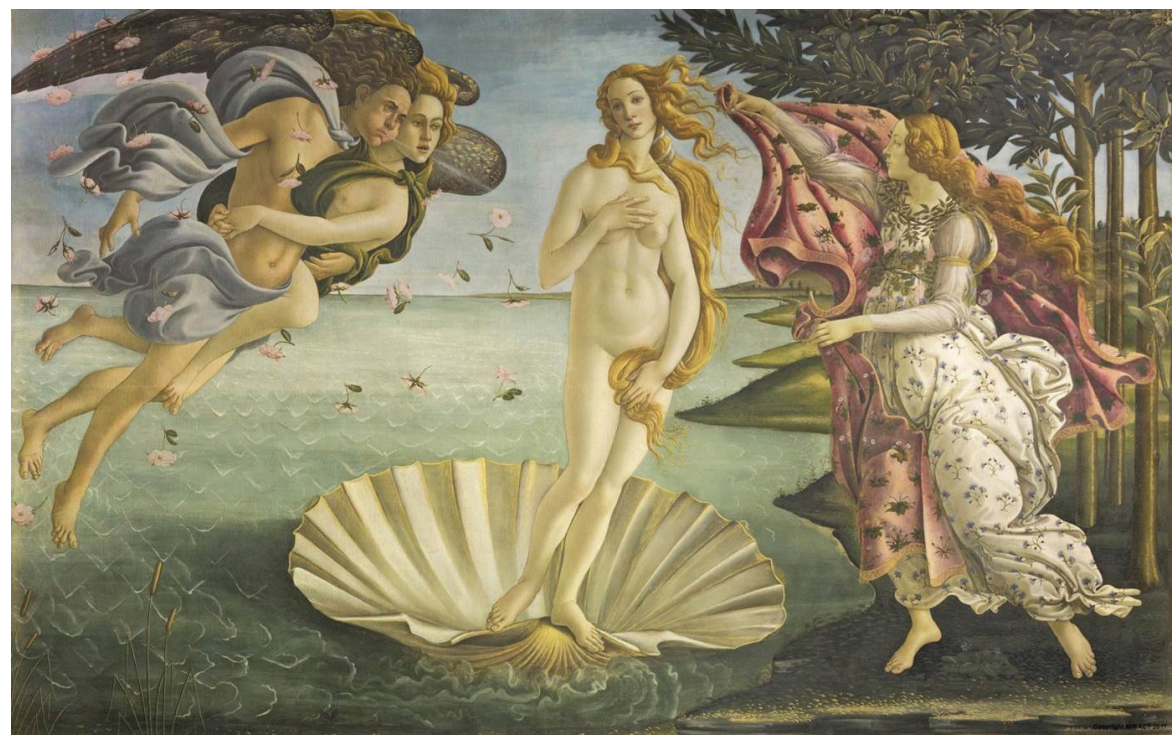

[Figura 2]

CASTELFRANCO,

Giorgione da. Vênus

Adormecida. c. 1510

Óleo sobre tela, $108 \times 175 \mathrm{~cm}$

Cemäldegalerie - Dresden

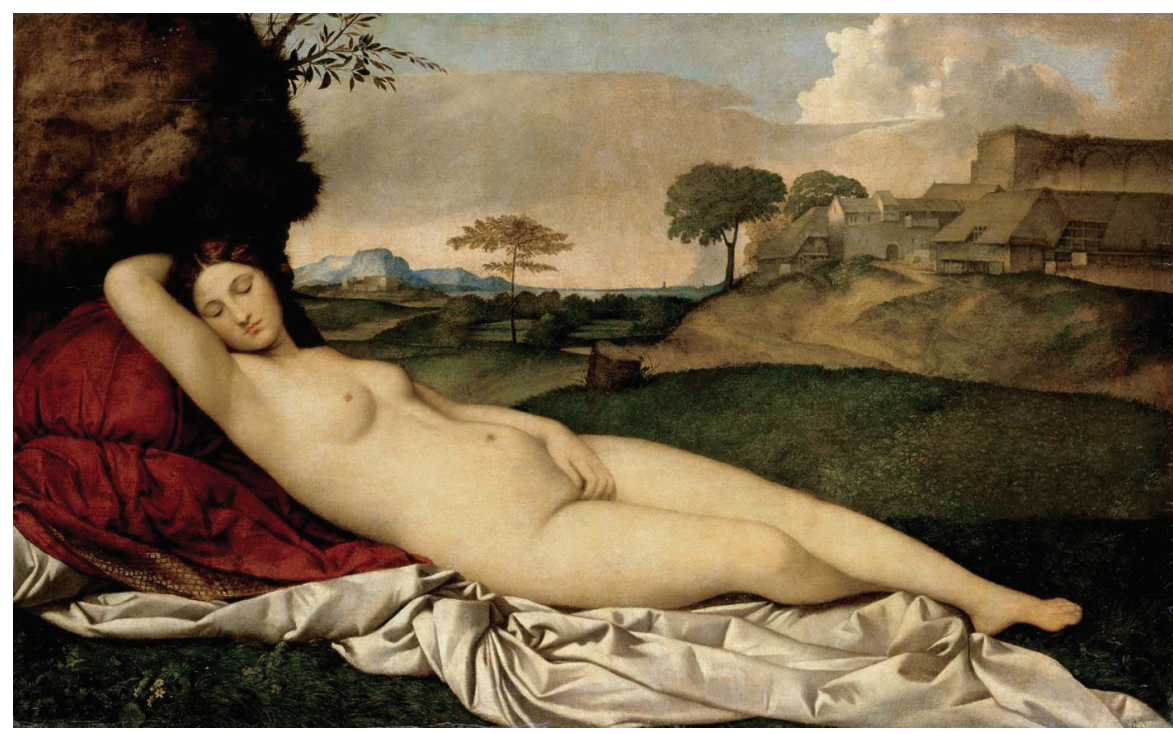

[Figura 3]

VECELLIO, Ticiano.

Vênus de Urbino. 1538

Óleo sobre tela, 119 cm x 165

$\mathrm{cm}$. Galeria dos Ofícios -

Florença

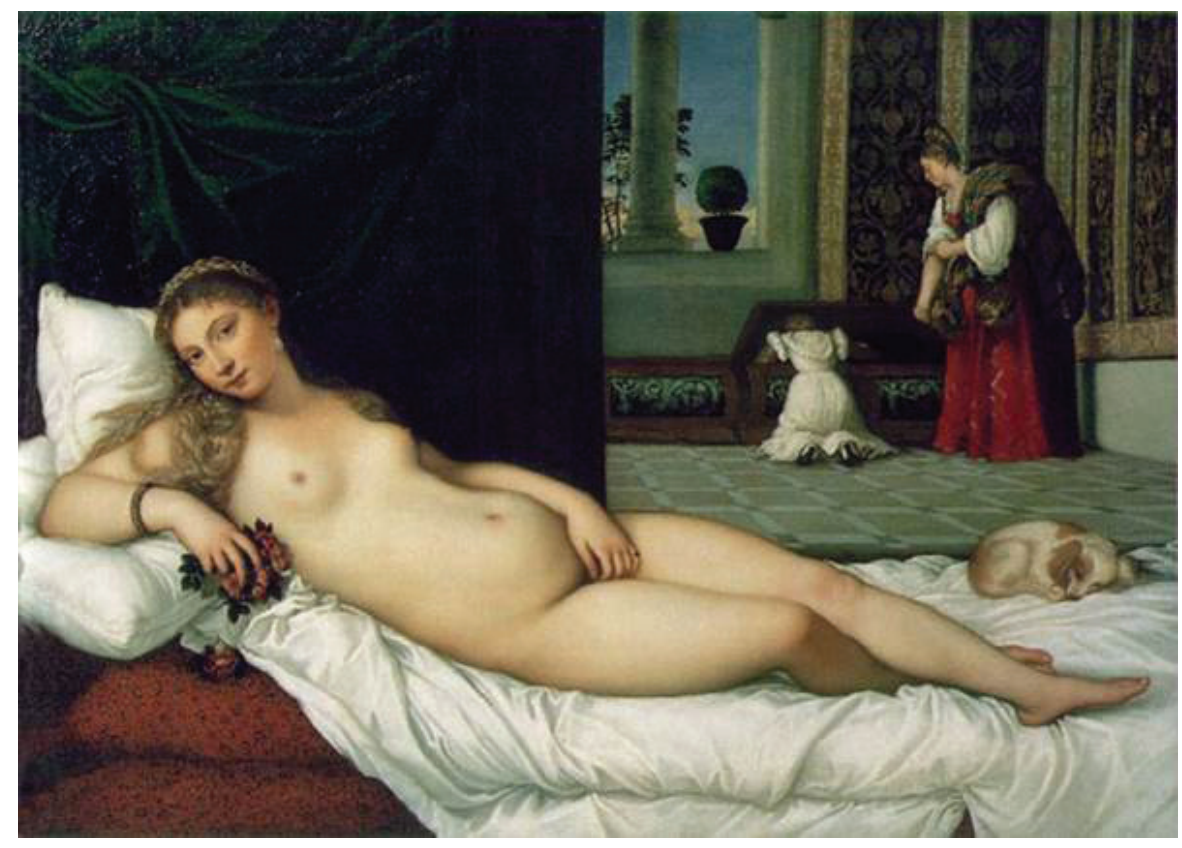


nas discussões sobre o tema². A inversão nesta hierarquia, proposta por Mário Equícola em seu Livro sobre a natureza do amor, no qual concede ao tato, ao invés da visão e da audição, a primazia entre os sentidos $^{3}$, foi uma proposição significativa e já observável no texto de Pietro Bembo, que embora também trate dos aspectos metafísicos, confere grande ênfase a descrições bem detalhadas dos aspectos físicos da "beleza ideal de uma dama"4.

No meio dos Medici, onde Botticelli trabalha e para quem, quase certamente, pintou O Nascimento de Vênus, há preferência por uma representação da beleza mais alinhada com as concepções metafísicas de Ficino, sobretudo nas pinturas mitológicas que, para vários autores, referem-se a conteúdos presentes em textos e cartas do filósofo, cujas traduções e comentários dos textos platônicos tiveram o financiamento dos Medici5. Neste círculo de eruditos, a mitologia foi revestida por novos valores e incorporada à filosofia e à literatura moral da época; e os atributos divinos da Vênus foram restituídos, convertendo-a de objeto de desejo físico, a um padrão de excelência espiritual $^{6}$. Entre as associações que permitiram à Vênus o resgate de sua interpretação pejorativa estava a definição de Ficino de Vênus-Humanitas ${ }^{7}$, um conceito que englobava o amor, a caridade, a liberalidade, a gentileza, a modéstia, o encanto e o esplendor. Para Ficino, este princípio moral era o mais adequado para conduzir um jovem às esferas superiores ${ }^{8}$. As Vênus de Botticelli estão inseridas neste contexto e, no Nascimento de Vênus, tema, interpretação e expressão visual alinham-se sob a chave neoplatônica, relacionando-se, diretamente, com a filosofia do amor de Ficino.

As Vênus vinculadas ao contexto de Veneza encontram-se, também, ao menos em parte, relacionadas ao tema das duas belezas e dos dois amores - celeste e terrestre. As associações estabelecidas por eruditos, artistas e comitentes venezianos com os temas do amor e da beleza refletem a cultura e os gostos locais, e resultam em uma abordagem distinta da florentina ${ }^{10}$. Além de integrar o tema clássico aos interesses e preferências dos patrícios, como a poesia pastoral, estabelece-se uma relação diferente com o tema mitológico, que afasta-se da filosofia, e aproximase dos manuais de conduta cortês e da "poesia', que se restabelece com força no ambiente Veneziano

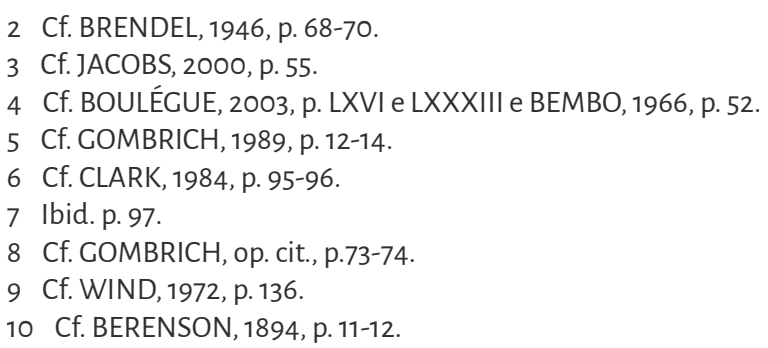


da época ${ }^{11}$. Na cidade lagunar, a beleza manifesta-se de forma mais original e natural, devido à pouca influência clássica e humanista até o século XV, o que permitiu uma abordagem mais física do belo, entendido como algo que visava, sobretudo, deleitar o olhar ${ }^{12}$. Um belo que poderia ser apreendido e fruído por todos os cinco sentidos, e não apenas pelo intelecto, pelos olhos e ouvidos, como defendiam os neoplatônicos. Uma transição identificável também nas pinturas que procuram, cada vez mais, incorporar e reproduzir, visualmente, estímulos táteis, os quais passam a ser, além de uma preferência dos comitentes, um critério de avaliação da maestria técnica dos artistas ${ }^{13}$.

Quanto à associação com a filosofia, nos tratados que circulam em Veneza esta tende a ser: ou uma síntese entre abordagens físicas e metafísicas, como nos Assolanos; ou uma abordagem puramente material, que reflete ideias como as de Nifo - que estabelece, por sua concepção puramente física da beleza, as bases de uma teoria naturalista do belo $0^{14}$ - ou as de Pietro Aretino, escritor próximo a Ticiano que considerava a verdade e a natureza as principais guias de um artista, além de defender o afastamento total do "pedantismo" do humanismo florentino; conceitos que, de acordo com Fritz Saxl, são visíveis na figuração da Vênus de Urbino ${ }^{15}$.

Em função do espaço disponível, esta comunicação terá foco sobre as correspondências: entre o Comentário de Ficino, e a figuração da Vênus no Nascimento de Vênus, de Botticelli; e entre os Assolanos, de Bembo, e a figuração da Vênus Adormecida, de Giorgione.

A ênfase sobre a importância da expressão por imagens foi frequente nos textos e cartas de Ficino, que acreditava em sua aptidão para transmitir e fixar na memória conceitos abstratos. Transformou a mitologia em chave de alegorias morais, e revestiu a ideia da beleza com um caráter supraceleste, fundamental para sua "Filosofia do Amor"16. Às Vênus couberam a representação de princípios morais e da beleza, em seus aspectos celeste e terrestre, e o Nascimento da Vênus representaria o "nascimento da beleza"17.

No que diz respeito à elaboração do Nascimento de Vênus, há um consenso sobre a fonte textual, em torno da Giostra, de Policiano e, indiretamente, dos Hinos Homéricos à Afrodite, especialmente o de número $\mathrm{VI}^{18}$. Sob o ponto de vista da iconografia, há um acordo sobre a referência ao

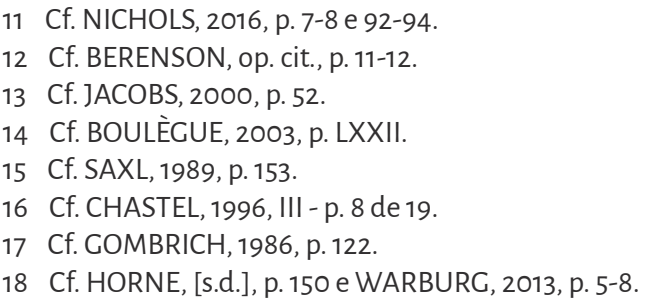


tipo da Vênus Pudica. A Giostra menciona na rima n ${ }^{\circ} 99$ : "Uma donzela com rosto não humano [...] Sobre uma concha guiada pelos ventos"19. A rima de $n^{0} 100$ fala do vento encrespando-lhe os cabelos e a 101 descreve a Vênus segurando os cabelos com a mão esquerda e cobrindo o seio com a direita. Mais adiante, faz referência a um semblante alegre e singular ${ }^{20}$. No Canto Homérico, aparecem menções à castidade, à formosura; a um "pescoço encantador" e a um "seio alvejante"21.

Apesar de identificáveis na imagem, estas menções não são suficientes para explicar a forma como estas características foram representadas na Vênus de Botticelli, e é aí que o Comentário de Ficino parece contribuir. Em seu texto, o filósofo relaciona a características formais como disposição, proporção e harmonia, - valores - como temperança, moderação e equilíbrio -, o que sugere que, pelo uso destes recursos, conforme esta modulação, seja possível aproximar a expressão visual resultante dos valores superiores da beleza que ele defende. Graça; harmonia entre as partes; harmonia nas cores e linhas; disposição natural e adequada; equilíbrio do conjunto; esplendor; graça reluzente e luminosidade são menções frequentes no Comentário, porém sempre acompanhadas por ressalvas que enfatizam um "preparo" não físico, anterior a todas estas manifestações²2.

Ficino define a beleza de um corpo como:

Atividade, vivacidade e uma certa graça reluzindo no corpo devido a infusão de sua própria "idea". Este tipo de luminosidade não é vertida sobre a matéria até que a matéria tenha sido cuidadosamente preparada. A preparação de um corpo vivente consiste nestas três coisas: disposição, proporção e ornamentação ${ }^{23}$.

Na sequência, enfatiza que são todas preparações incorpóreas ${ }^{24}$. Esta ressalva é mais facilmente compreensível quando analisamos estátuas antigas que seguem o modelo da Vênus Pudica e as comparamos à Vênus do Nascimento de Vênus (Figura.4): apesar da pose, da disposição natural e adequada das partes, e da correção das proporções, estas não expressam as ideias de transcendência, moderação e temperança apreensíveis na pintura de Botticelli.

Sobre as características que permitem superar a mera expressão física, Ficino comenta:

Proporção não é quantidade, mas limite de quantidade; estes limites são superfícies, li-

\footnotetext{
9 Cf. POLICIANO apud WARBURG, op. cit., p. 7.

20 Ibid., p.7.

21 Cf. HOMERO apud WARBURG, op. cit., p. 8.

22 FICINO, 1944, p. 171 e 174.

23 Ibid., p. 173. Tradução livre do original: "[...] Activity, vivacity, and a certain grace shining in the body because of the infusion of its own idea. This kind of glow does not descend into the matter until the matter has been carefully prepared. The preparation of the living body consists in these three things: Arrangement, Proportion, and Adornment."

24 Ibid., p. 174.
} 

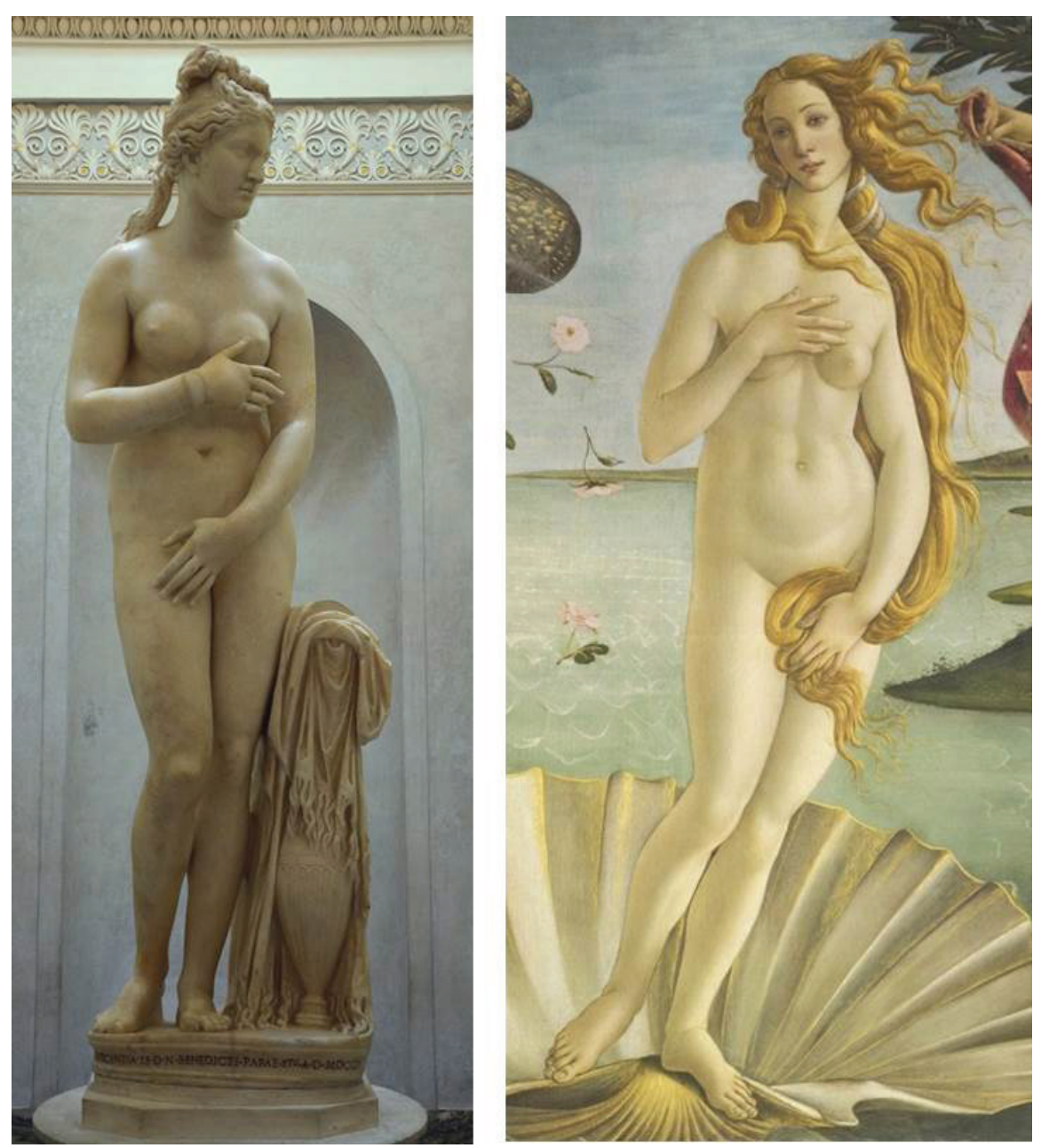

[Figura 4] Vênus Capitolina c. 96 d.C.-192 d.C. - variação do modelo da Vênus Pudica, derivada da Afrodide Cnídia, de Praxíteles (séc. IV a.C.). h. $193 \mathrm{~cm}$. Musei Capitolini. Roma e detalhe do Nascimento de Vênus, de Botticelli. De acordo com Kenneth Clark (1984), a Vênus Capitolina é a variação da Vênus pudica que mais se aproxima da iconografia da Vênus de Botticelli. 
nhas e pontos que, uma vez que não possuem massa e profundidade, não são considerados corpos. A ornamentação também, nós entendemos como uma harmonia agradável de luzes, sombras e linhas, mas não na matéria ${ }^{25}$.

Giulio Carlo Argan defende que a pintura de Botticelli expressa estes conceitos ao exaltar o "andamento rítmico e musical da linha, a qual não visa tornar-se limite ou contorno, desenvolvendo a figuração em uma dimensão irredutível a um espaço e tempo concretos"26. Na figuração da Vênus de Botticelli, o gesso à base de alabastro, a têmpera magra, e as cores frias fazem com que a Vênus pareça resplandecer, emanando uma luminosidade difusa. O modelado que define a silhueta é sutil, revelando as formas sem criar uma sombra que remeta à ideia de um corpo denso, o que reforça a impressão de um ser feito por matéria etérea. Há também a sensação de leveza criada pela ondulação dos cabelos e reforçada pela impressão de movimento contínuo e ascendente, que parte das nervuras da concha e segue pelo contorno do corpo vertical, sugerindo um fluxo permanente entre o material e o superior. A paleta suave, o aspecto escultórico, a pose contida, e o olhar sereno e melancólico, evocam um ideal de contemplação e transcendência, uma beleza que, embora atraente, convida a ir além e vislumbrar domínios superiores.

Em Veneza, no tempo de Giorgione, surge um novo tipo de público para a pintura, com preferência por temas seculares, que estimulem o debate; celebrem o prazer e a vida; e deleitem o olhar, inspirando-se em vivências experimentadas sensorialmente ${ }^{27}$. No início do Quinhentos, nos tratados que derivam do de Ficino, a beleza e o amor são debatidos em perspectivas que vão desde as mais carnais, até as mais elevadas ${ }^{28}$. $\mathrm{O}$ aprimoramento da técnica de pintura, possibilitado pela tinta a óleo e pelo emprego do sfumato, somado a um melhor conhecimento da anatomia, impulsiona mudanças nos padrões da beleza feminina. O ideal veneziano é o da mulher desabrochada ${ }^{29}$.

A figuração da Vênus Adormecida, de Giorgione reflete este segundo momento da difusão dos tratados sobre o amor. Integrando um tema clássico, representado à antiga, a uma paisagem moderna, alinha-se ao gosto Veneziano e chama a atenção por uma alteração essencial: se a Vênus de Botticelli surge contra um fundo mais "abstrato" sugerido pela passagem quase esquemática porém contínua e ascendente - do verde do mar ao azul do céu; a Vênus de Giorgione encontra-se

25 Ibid., loc.cit. Tradução livre do original : "[...] Proportion is not quantity, but limit of quantity; these limits are surfaces, lines and points, which, since they lack mass and depth, are not considered bodies. Adornement also, we place in a pleasin harmony of lights, not in matter." 26 ARGAN, 1989, p. 14-com adaptações.

27 Cf. BERENSON, 1894, p. 12.

28 Cf. BAYER, 2008 a, p.6.

29 Cf. CHASTEL, 2012, p. 388-389. 
cercada pela natureza, que constitui seu elemento e ambiente original ${ }^{30}$. Andrea Bayer sugere que sua fonte textual tenha sido um epitalâmio romano escrito por volta do ano 400, que mencionava a Vênus adormecida ao ar livre sob o Sol ${ }^{31}$; e Emilie Séris propõe como fonte as poesias pastorais do próprio Pietro Bembo ${ }^{32}$ que, segundo Mariane Koos, estava em contato com praticamente todos os comitentes de Giorgione ${ }^{33}$. Sobre a fonte iconográfica, Saxl destaca uma gravura do Sonho de Polífilo, de Francesco Colonna, que mostrava uma ninfa adormecida à beira de uma fonte ${ }^{34}$. $\mathrm{O}$ texto trazia uma longa descrição da ninfa, que não tem elementos comuns com a beleza representada na pintura.

Os trechos a seguir demonstram que nos Assolanos, de Bembo, há definições e descrições cujas expressões visuais são identificáveis na Vênus Adormecida. O Livro III concorda com Ficino e define o amor como um desejo de beleza, ressaltando que é belo o corpo cujos membros têm proporção; e é bela a alma cujas virtudes encontram-se em harmonia. No Livro II, porém, há uma descrição bem física e muito específica da "beleza ideal de uma dama", que apresenta vários aspectos em comum com a pintura. Bembo menciona:

[...] uma bela trança [...] cílios de ébano lisos [...] bochechas macias, cuja suavidade e alvura assemelham-se àquela do leite, e quando não, competem com o colorido [...] das rosas da manhã. [...] a boca, contida em um pequeno espaço [...], como dois pequenos rubis, vivos e doces $[\ldots]^{35}$.

Sobre os cabelos, fala ainda em "[...] um novo milagre de puro âmbar, palpitante em uma fresca camada de neve [...]"36. A observação desta beleza afasta-se completamente da apreciação didática e reverente de uma beleza transcendente.

Bembo fala, ainda, em avaliar esta beleza, fruindo, inclusive, o que está por trás da veste e, em outro momento, faz referência a despir mentalmente a modelo, enumerando características físicas e morais: "Quão [prazeroso] depois, em sua vestimenta reentrando, considerar a doçura, a delicadeza, a graciosidade, a razão, a virtude, o espírito e suas belas partes?"37, uma atitude que de-

\footnotetext{
30 Sobre a aproximação de Botticelli com a linguagem visual abstrata na representação do "espaço pictórico", Cf. ARCAN, op. cit. p. 14-16 e sobre a associação com a natureza na Vênus Adormecida, de Giorgione: Cf. VENTURI, 1960, p. 27-28 e SAXL, 1989 , p. 150 e 153.

31 BAYER, 2008b, p. 236.

32 SÈRIS, 2011, p. 201-201.

33 KOOS, 2000, p. 373.

34 Cf. SAXL, 1989, p. 149.

35 BEMBO, 1966, p. 52. Tradução livre do original:"[...] la bella treccia [...] le ciglia d'ebano piane [...] le morbide guancie, la loro tenerezza e bianchezza con quella del latte [...], se non in quanto alle volte contendono con la colorita [...] delle matutine rose [...] bocca, di picciolo spazio contenta, con due rubinetti vivi e dolci $[\ldots]$..

36 Ibid. p. 52. Tradução livre do original : "[...] un nuovo miracolo di pura ambra palpitante in fresca falda di neve [...]".

37 Ibid. p. 57. Tradução livre do original: "[...] Quanto poi, ne' costumi di lei rientrato, la dolcezza considerare, la cortesia, la leggiadria, il senno, la virtù,
} 
nuncia a contemplação desta beleza como fonte de prazer estético e sensorial, e não como meio de ascensão a domínios mais sutis.

A imagem de Giorgione expressa uma síntese semelhante entre as ênfases conceituais - harmonia, proporção, disposição adequada - e as características físicas específicas - os traços do rosto, a cor e o penteado dos cabelos, a carnação macia, as formas arredondadas que sugerem firmeza. Uma síntese que também foi observada pelos que analisaram a pintura, e que pode explicar as conclusões divergentes sobre tratar-se de uma beleza e de uma Vênus "celeste ou terrestre", o que também está de acordo com a visão de Bembo que, embora tenha feito distinção entre as belezas do corpo e da alma, não repetiu a correspondência de valores - inferior e superior - presentes em Ficino, considerando as duas igualmente ${ }^{38}$. A figuração de Giorgione acompanha os discursos sobre o amor de Pietro Bembo ${ }^{39}$ ao apresentar características como: a relação entre o tema clássico e o ambiente bucólico que remete ao ideal arcádico; as qualidades físicas particulares alinhadas a uma atitude contemplativa e idealizada - potencializada, na imagem, pelo ato de dormir.

O sono implica um distanciamento do mundo real e um estado de idealização que estabelece uma "barreira" entre a deusa adormecida e seu espectador ${ }^{40}$. Esta Vênus pertence, sem dúvida, ao domínio do natural, porém, apesar da cor de carne, da luz dourada que incide sobre ela e do modelado arredondado, que sugere um corpo concreto, a associação que se cria é a de um ser “intermediário" entre o real/natural e o divino/superior. O aspecto contemplativo da figura nua, e a correspondência entre os ritmos das formas da Vênus com as da natureza que a envolve também são significativos, uma vez que os cabelos cor de âmbar criam uma continuidade entre a cabeça e o monte onde está apoiada e a linha descendente, que se forma da cabeça à paisagem, enfatiza a associação com o natural. A ideia de geração é reforçada pela posição da mão que evidencia a região da púbis.

Nos tratados posteriores ao de Ficino, as normas éticas e intelectuais foram substituídas pelos critérios da graça e da beleza física e pode-se concluir que estas novas teorias, com suas respectivas definições de beleza, têm potencial para explicar uma progressiva mudança de gosto e as consequentes alterações estilísticas que ocorrem em função disso, que conduzem a representações cada vez mais distantes da beleza transcendente preconizada por Ficino.

\footnotetext{
l'animo ele sue belle parti? [...].

38 Cf. BRENDEL,1946, p. 69.

39 CF. KOOS, 2000, p. 373.

40 Cf. MEISS, 1966, p.359.
} 
Na representação de Botticelli, tema, interpretação e expressão visual encontram-se alinhados sob os conceitos ficinianos da beleza metafísica. Em Giorgione, a Vênus exibe uma beleza mais "tátil" e corpórea que, no entanto, ainda remete à ideia de contemplação. A sugestão de uma existência idealizada é reforçada pelos olhos fechados e pelo ambiente bucólico que a rodeia. Na Vênus de Urbino, de Ticiano, o conteúdo mitológico é quase completamente absorvido pela materialidade da expressão visual, que refuta todo o conteúdo filosófico, privilegia a "verdade" da imagem em uma representação quase "realista", seguindo a orientação de Aretino de guiar-se pela natureza e pela verdade, evidenciando também a maestria técnica na representação de um belo corpo.

Parece plausível, portanto, estabelecer uma relação entre as definições veiculadas nos tratados e diálogos sobre o amor, e as mudanças na figuração da Vênus que, ao que tudo indica, acompanharam as adaptações do conteúdo original, exibindo também uma crescente materialização do conceito de beleza.

\section{Referências Bibliográficas}

ARDURA, Rocío de la Villa. Introduction In: FICINO, Marsilio. Comentario a El Banquete de Platón. Tradução, apresentação e notas: Rocío de la Villa Ardura. $3^{\text {a }}$ edição. Madri: Editora Tecnos, n.p., 2001.

ARGAN, Giulio Carlo. Botticelli. Firenze: Skira Newton Company, 1989.

BAYER, Andrea. Introduction. Love and Art in Renaissance Italy. In: BAYER, Andrea. (Org.) Art and love in Renaissance Italy. London: Yale University Press, p.3-8, 2008 ${ }^{\mathrm{a}}$.

BAYER, Andrea. From Cassone to poesia: Paintings of love and marriage. In: (Org.) Art and love in Renaissance Italy. Londres: Yale University Press, p.230-237, 2008b.

BEMBO, Pietro. Cli Asolani. Curadoria: Carlo Dionisotti. Torino: E-Text, 1966. Disponível em:< https://www.liberliber.it/ online/autori/autori-b/pietro-bembo/gli-asolani/sacessado em 30 de agosto de 2019.

BERENSON, Bernhard. The Venetian Painters of the Renaissance with an index to their work. New York: G. P. Putnam's sons, 1894.

BOULĖCUE, Laurence. Introduction. In: NIFO, Agostino. Du Beau el de L'Amour. Le Livre du Beau. Tradução: Laurence Boulègue. Paris: Les Belles Lettre, 2003.

BRENDEL, Otto. The Interpretation of the Holkham Venus. The Art Bulletin, v. 28, n. 2. Art College Association. jun. , p. 65-75, 1946.

CHASTEL, André. Arte e Humanismo em Florença. São Paulo: Cosac Naify, 2012. .III- Pater Platonica Familiae in: Marsile Ficin et l'art. Cenève: Librairie Droz S.A., p.

47-64, 1996.

CLARK, KENNETH. The Nude. A Study in ideal form. New Jersey: Princeton University Press, 1984.

COOK, M. A. Herbert. Giorgione. [s.I.]: Barrister-at-Law, 1904. 
FICINO, Marsilio. Commentary on Plato's Symposium. Tradução: Sears Reynolds ]ayne. Columbia: University of Missury, 1944.

COMBRICH, Ernst. Imágenes Simbolicas: Estudios sobre el arte del Renacimiento. Tradução: Remigo Cómez Díaz. Madrid: Alianza Editorial. 1986.

HORNE, Herbert, Sandro Botticelli. London: Chiswick Press, [s.d.].

JACOBS, Frederika H. Aretino and Michelangelo, Dolce and Titian: Femmina, Masculo, Grazia. The Art Bulletin, v. 82, n. 1. Art College Association, mar, p. 51-67, 2000.

JAYNE, Sears Reynolds. Introduction In: FICINO, Marsilio. Commentary on Plato's Symposium. Tradução: Sears Reynolds Jayne. Columbia: University of Missury, p. 13-33, 1944.

KOOS, Mariane. Imagination, Identity and the Poetics of Desire in Ciorgione's Painting. American Imago, v. 57, n. 4, p. 369-385, winter, 2000.

MEISS, Millard. Sleep in Venice. Ancient Myths and Renaissance Proclivities. Proceedings in American Philosophical Society. [s.I]: v.110, n.5, Oct. 27, 1966.

NICHOLS, Tom. Renaissance Art in Venice. From Tradition to Individualism. China: Laurence King Publishing, 2016.

NIFO, Agostino. Du Beau el de L'Amour. Le Livre du Beau. Tradução: Laurence Boulègue. Paris: Les Belles Lettre, 2003.

PANOFSKY, Erwin. Studies of Iconology. Humanistic Themes in the Art of the Renaissance. New York: Icon Editions, 1972. Idea: Evolução do conceito do Belo. Tradução: Paulo Neves. São Paulo: Martins Fontes, 1994.

SAXL, Fritz. La vida de las Imágenes. Estudios Iconográfios sobre el arte occidental. Tradução: Frederico Zaragoza. Madrid: Alianza, 1989.

SÈRIS, Emilie. La renaissance du nu antique à Venise: Pietro Bembo et le Titien. International Journal of the Classical Tradition. v. 18, n. 2, p. 201-225, June. 2011

VENTURI, Lionello. Cuatro passos hacia el arte moderno. Tradução: Luis Fabricant. Buenos Aires: Ediciones Nueva Visión, 1960.

WARBURG, Aby. A Renovação da Antiguidade Pagã. Contribuições científico-culturais para a história do Renascimento europeu. Tradução: Markus Hediger. Rio de Janeiro: Contraponto, 2013.

WIND, Edgar. Los Misterios Paganos del Renacimiento. Tradução: Jávier Fernándes de Castro e Julio Bayón. Barcelona: Barral Editores, 1972. 